seventeenth year detected an error of reasoning in Laplace's "Mécanique cóleste". At Trinity College, Dublin, he was first in all his examinations and, while still an undergraduate, he predicted in 1833 by the aid of mathematics the internal conical refraction of light, which was verified experimentally in the same year by $H$. Lloyd. Hamilton was then appointed John Brinkley's successor in the chair of astronomy; he later became Astronomer Royal for Ireland. From 1843 onwards Hamilton devoted his life to the elaboration of his theory of quaternions, which was announced in "Lectures on Quaternions" (1853) and posthumously in "Elements of Quaternions" (1866). As a writer he was sometimes obsoure and metaphysical, but he excelled as a fluent and ornate lecturer. He was knighted in 1835, was elected president of the Royal Irish Academy in 1837, and died on September 2, 1865 , at the age of sixty, worn out physically and mentally.

\section{Shortage of Scientific Workers and Teachers in Great Britain}

IN a debate in the House of Lords on July 5 on exemption from National Service, Lord Cherwell pressed again for the exemption of highly trained scientific workers, especially those engaged in highgrade research in the universities. Lord Cherwell suggested that there was great lack of balance in limiting deferment to fifty such scientists in a year when eight thousand agricultural workers are deferred each year; but Lord Carrington, replying for the Government as Parliamentary Secretary to the Ministry of Defence, stated that the Government has not yet received fifty applications from the universities for deferment under this scheme, and thought that it is much too early to judge how well this scheme, introduced earlier this year, is working. Lord Carrington also referred to a scheme, introduced since 1949, under which science and engineering graduates have been deferred for employment on a limited number of research and development projects mostly connected with the defence programme; and ho emphasized the need of the Armed. Services for technical graduates, particularly for younger workers with dogroos in engineering, physics and mathematics. It has been estimated that in 1955 the Services will recruit less than half their requirements, and graduates in seienee are also badly needed by the education branches of all three Services for teaching in technical training colleges.

The debate was thus related to an adjournment debate in the House of Commons later in the week on the shortage of science teachers - a matter to which Lord Cherwell also referred, as did Lord Hull and Lord Glyn, whose purpose in tabling the motion was to emphasize the importance of giving technical and technological education and research a very high place in the affairs of the country. In raising this question in the Commons on July 8 and asking the Government what steps it proposes to take to meet the shortage, Dr. Horace King supported the exomption of science teachers from national service, or at least the exemption of those who had completed their initial or basic training, and Mr, E. C. Willis pointed out that the Appleton Committee had recommondod the oxemption of teachers with first- or second-class honours in mathematics, physics or chemistry, as being the only sure means of getting more teachers quickly. In replying for the Government, Mr. Dennis Vosper, Parliamentary Secretary to the Ministry of Education, declined to discuss the question of deferment; he pointed out that the teaching profession itself is divided on the question, that deferment would make a comparatively small contribution to the removal of the shortage, and that it would involve a breach in the principle of universality. He did not think that too much importance should be attached to the proposal in trying to solve the larger problem. Mr. Vosper said that the present shortage of science teachers is less than expected, recruitment having exceeded the forecast; during the period March 1952-Mareh 1954, the number of graduate science and mathematics teachers in maintained primary and secondary schools in England and Wales increased from 11,022 to 11,615. The main difficulty is in quality, and the real gravity of the problem was in the anticipated increase of 650,000 in the number of senior pupils by 1960 compared with 1954, with the consequent demand for a further 3,200 graduate science teachers. Mr. Vosper referred to the possibility of making conditions of service more attractive for teachers of science and mathematics, and said that the Minister hopes shortly to advise local education authorities as to the possibility of paid leave to teachers to take part in research; but he thought that the real solution to the shortage lies in a change in the public esteem of the teaching profession and an increasing public awareness of the needs of science.

\section{Personnel Research in the Royal Navy}

THe record during the Second. World War of the Royal Navy's concern with the safety and efficiency of its personnel can be found in the volume on medical research in the "Official Medical History of the War" (1953). In the post-war period the alliance between the Navy and the Medical Research Council in this field of research has continued vigorously and fruitfully. An up-to-date survey of naval personnel research (Admiralty Bulletin 67, pp. 12; Department of Chief of Naval Information, Admiralty, London, S.W.1; 1955) has now been written by Surgeon-Commander Crosfill, the present secretary to the Royal Naval Personnel Research Committee. The survey is a record of progress both in occupational hygiene and that branch of operational research for which the name ergonomics has been coined and which is concerned with the efficiency of the operator in his working environment. Commander Crosfill gives an informative and readable account of the important work sponsored by the various sub-committees of the main Committee. It is quite clear that the ad hoc work has nearly always been based on, and been a fruitful source of, much fundamental investigation. This is evident, on the psychological side, in studies of multi-channel communication, of various kinds of pressure and velocity control systems, and the effects of noise, all of which raise fundamental questions of vigilance, perception, proprioceptive 'feed-back' and skill. On the physiological side, studies of working efficiency in abnormal climates have yielded a great deal of basic data on human heat regulation, acclimatization and limits of heat tolerance and have led to improvements in the dosign of climatological 'indices' and the introduction of the ionization anemometer. Perhaps the most spectacular of the investigations is that sponsored by the underwater physiology sub-committee in connexion with the problem of submarine escape. This work has led to the development of the technique of escape by 'free ascent', and has made a 